\title{
USING TREES TO CREATE HABITATS WITHIN A BOTANIC GARDEN
}

\author{
Ericka Witcher ${ }^{1}$
}

\begin{abstract}
Botanic gardens bring plants from all over the world into one small place for people to admire and study. The challenge lies in creating a suitable habitat for specimens from widely disparate regions in the garden environment. Plants have specific environmental requirements which have to be considered for successful cultivation, but sometimes these are not naturally present and instead must be provided. This paper discusses the ecological utility of large trees in the context of the botanic garden for other plants to flourish.
\end{abstract}

\section{INTRODUCTION}

Humankind has long been fascinated by botanical beauty, from the time of the ancient Hanging Gardens of Babylon to the parks, gardens and houseplants of the present day. Likewise, for millennia people have planted gardens to use for food, textiles and tools, and continually sought out new varieties to enhance their collection (Hobhouse, 2004). Today, a botanic garden brings together exotic plants from around the globe into one venue, where they may be admired and studied. It combines pleasing aesthetics with the academic goals of conservation and scientific inquiry. As areas of high endemic biodiversity continue to dwindle (Brooks et al., 2002), ex situ collections matter more than ever (Guerrant et al., 2004). In order to maintain these plants outside of their natural habitat, however, a suitable environment must be constructed.

There are many elements that influence the design of a garden: topography, altitude, latitude, proximity to water bodies, weather patterns, human use interface and local flora. In turn, plants have different needs and preferences for soil composition, light availability and water. Landscape design for a botanic garden should aim to incorporate the aesthetic value of a garden as visitor attraction while providing for the needs of the specimens contained within. This presents a multifaceted challenge: combining different plants from many different climes into one foreign habitat, creating an ecosystem that is artificial yet functional.

An obstacle looming large in this challenge is that many gardens are a small sample of their own surrounding landscape, resulting in topography that is mostly homogeneous; the plants, however, come from within landscapes that are part of mountain ranges, valleys and plains that are ecologically complex and exist on a much more

1. Ericka Witcher is Collections Supervisor at Montgomery Botanical Center. Address: 11901 Old Cutler Road, Coral Gables, FL 33156, USA.

Email: erickaw@montgomerybotanical.org 
expansive scale. At Montgomery Botanical Center (MBC), as in many other gardens, we must use trees not just as eye-catching specimens or aesthetic backdrops but to create microhabitats that mimic the growing conditions of places all over the world - the trees become a kind of biological topography for each other and other plants.

MBC has more than 13,000 individually accessioned plants planted out in the garden, representing 1,149 taxa. Unlike many other gardens, the emphasis of our population-based collections is not on dicotyledonous flowering plants, but on cycads, palms and tropical conifers which together comprise more than 80 per cent of our accessions. Most are grown from wild-collected seeds and would be difficult to cultivate anywhere else in the US. Of these accessions, 25 per cent are IUCN red-listed. MBC is located on the south-east end of the Florida peninsula in Miami-Dade County. The 118 acre (48 hectare) property is adjacent to mangrove swamp and approximately 50 acres (20 hectares) of clay-like marl soil are near sea level, becoming inundated during spring and autumn high tides. The remaining 70 acres (28 hectares) are comprised of an oolitic limestone bedrock/sand matrix which averages $4 \mathrm{~m}$ higher in elevation and generally drains freely. Both areas are fairly uniform in soil composition, and the elevation within each area remains mostly flat (Witcher \& Griffith, 2011).

\section{TREES AS SUBSTITUTES FOR TOPOGRAPHICAL ELEMENTS}

A canopy elevation map clearly shows that trees are the tallest and some of the widest natural features on the property (Fig. 1), and as such their primary function in our garden ecosystem is to provide shade. Miami is in USDA Hardiness Zone 10b: a sub-tropical climate with mild winters, relatively intense sunlight, high humidity and high summer temperatures (PRISM and USDA, 2012). Although many plants flourish wherever they are planted at $\mathrm{MBC}$, the collections also include plants from cooler, tropical montane areas, polar-facing slopes, cliff sides and canyons, in addition to those whose niche is within deeper shade in forests and jungles. Many studies have shown that trees can lower temperatures in their immediate vicinity; Shashua-Bar \& Hoffman (2004) is one of these. Because we lack mountains at MBC, we put trees to work instead as cooling shade providers. There are thousands of shade-providing trees and palms at MBC, but those of primary use are some of the older, larger specimens of the 40 fig trees (namely Ficus altissima, F. aurea, F. benjamina, F. citrifolia, F. lyrata, F. microcarpa and $F$. subcordata) growing amidst the collections and a network of over 650 Quercus virginiana (Virginia live oak) which are native to the property. Like many dicotyledonous plants in tropical areas, these trees are evergreen and replace leaves year-round, with an extra flush of new leaves in the spring. The fig canopies are dense and dark, and the enormous size of many of these specimens creates another world unto themselves (Fig. 2). In contrast, the oaks have more dappled canopies with filtered light, and their smaller overall size allows them to be placed in closer, continuous plantings. By making planting for smaller species on the edges or well under the canopy of these large trees 


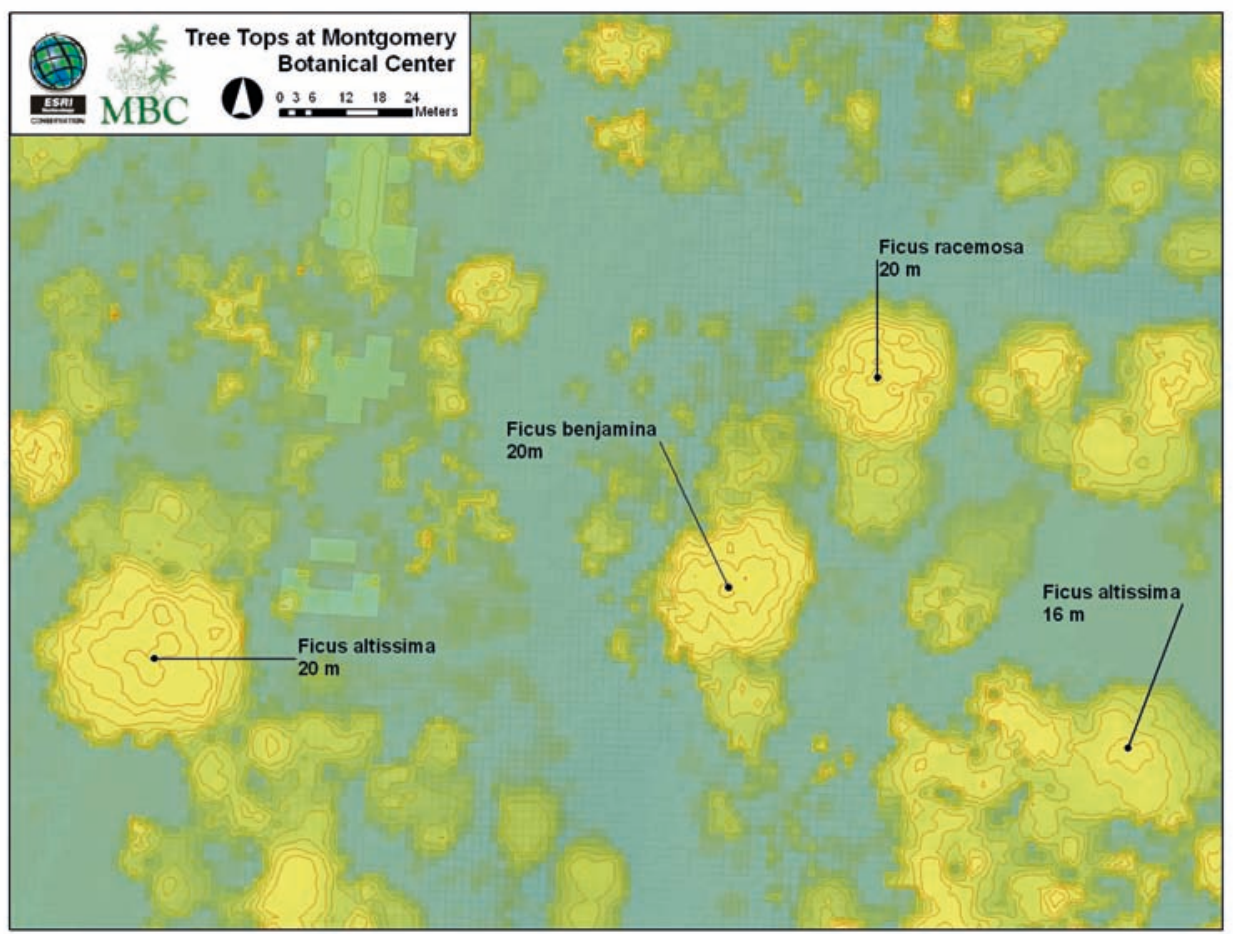

Fig. 1 Section of canopy elevation map for MBC showing contours above $10 \mathrm{~m}$ high every $1.5 \mathrm{~m}$, with major peaks labelled by species. Photo: Ericka Witcher.

they have growing conditions with reduced sun intensity and temperatures, yet enough sunlight for the understorey plants to grow.

At the other end of the temperature spectrum are the near- or at-freezing temperatures sometimes experienced in Miami in winter. While they rarely last for more than a few days at most as a cold front rolls through, this can be too long for some of the tender tropical plants. Here, too, trees are used to create microhabitats of warmer, higherhumidity pockets of air. This is accomplished mainly by trees acting as windbreaks to block chilling winter winds and as shelter against the pooling of cold air. Within their protective canopies, the air temperature and relative humidity are higher than the ambient weather during these cool periods (Feldhake, 2002), often by just enough to keep the more delicate palms and cycads from dying of cold exposure. Plants from equatorial regions which rarely see temperatures colder than $10^{\circ} \mathrm{C}$ (Magarey et al., 2008) receive particular attention and priority with regard to these protective planting locations. At the north end of the property, native and exotic specimens of tall trees mixed with the Caribbean palm (Coccothrinax barbadensis) form a lush backdrop to a formal colonnade of royal palms (Roystonea regia) lining the main drive. Sheltered here are Chamaedorea, Calyptrocalyx and Ceratozamia species, along with other palms, cycads and a number of tropical conifers from Africa, Central America and the South 


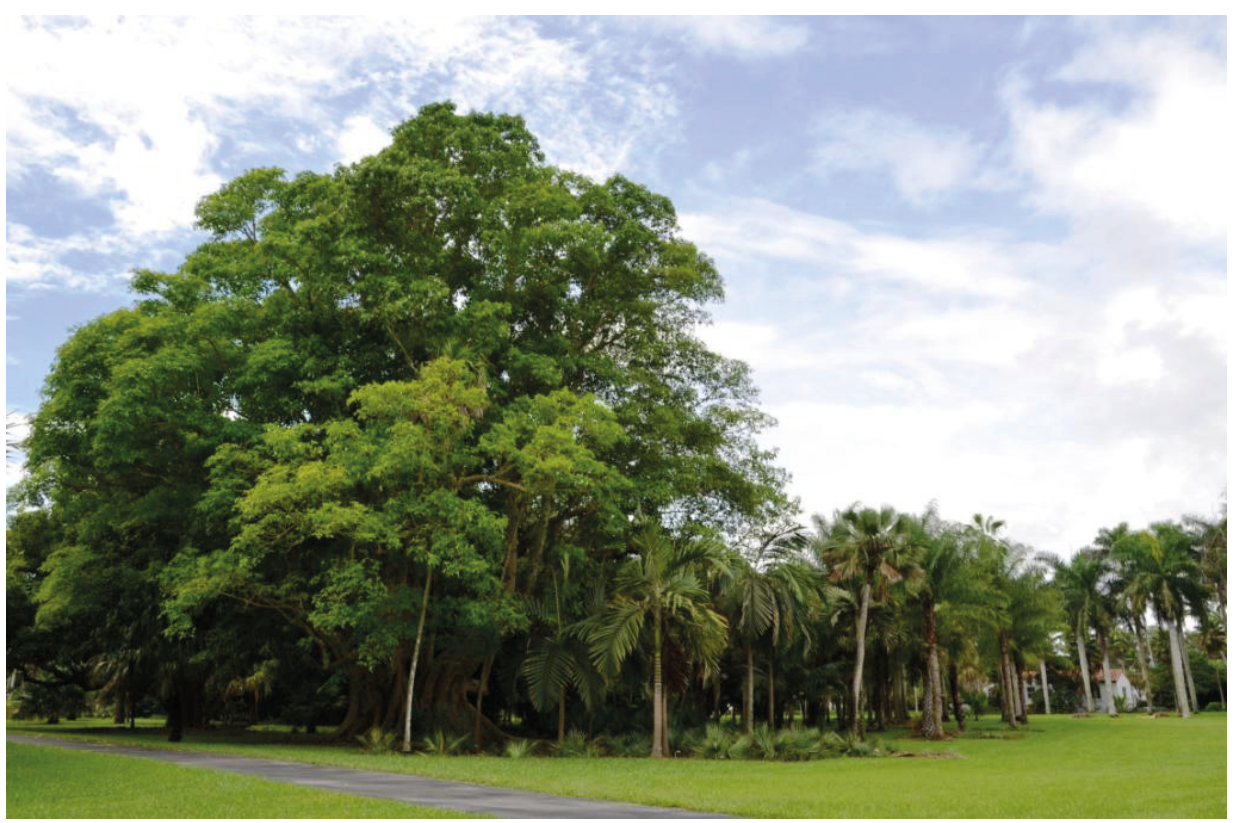

Fig. 2 At $20 \mathrm{~m}$ high and $30 \mathrm{~m}$ across, this Ficus racemosa is both visually striking and creating a habitat for more than 200 palms and cycads from regions as diverse as New Caledonia, Japan and Honduras. Photo: Ericka Witcher.

Pacific. These plants thrive together in the sand pockets and shade, and are protected from both summer and winter extremes in the interlacing canopies of the larger plants (Fig. 3).

Mulch is also frequently used for protection against cold weather and is freely available under dicot trees with leafy canopies. When it is combined with underground root growth, it serves another purpose too: that of alleviating some of the harsh effects of the very alkaline soil. South Florida is characterised by relatively new soil $(<15,000$ years old), which is thin and primarily derived from alkaline ( $\mathrm{pH} 8.3-8.4)$ white oolitic limestone bedrock, which is exposed to the surface in higher areas, and interspersed with pockets of sand. Lower-altitude areas are made up of wetland muck and clay-like marl (USDA, 2013). Layer after layer of leaf litter, over time, can lower the $\mathrm{pH}$ and make the soil less harsh than weathering alone does, certainly in the topmost layers of soil (Reich et al., 2005; Scharenbroch et al., 2013). As roots grow they help to mix and add to these layers. A less alkaline $\mathrm{pH}$ improves the Cation Exchange Capacity (CEC), which is essential to plants' ability to take up minerals found in the soil and supplemental fertiliser. This is exemplified by Syagrus ruschiana, a sensitive palm from Brazil that has only survived under the branches of an older conifer, Callitris glaucophylla (from Australia), where the soil is now less alkaline, thanks to years' worth of continual shedding of acidic leaves from the conifer onto the soil around it.

The texture and composition of mulch-mixed soil is also preferential for many 


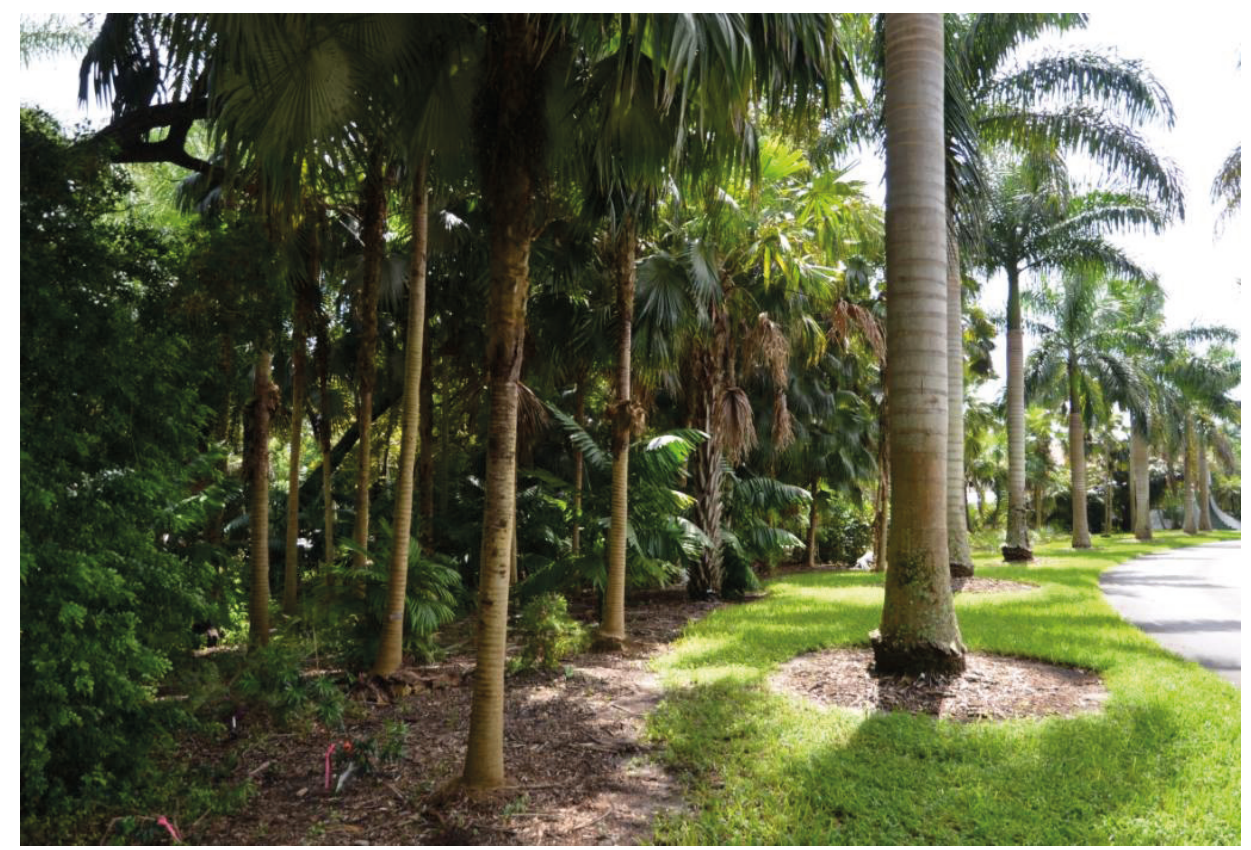

Fig. 3 The lush backdrop of trees and palms for the Royal Palm Colonnade (Roystonea regia), a formal design element lining the main drive, also shelters a variety of cold- and heat-sensitive palms, cycads and tropical conifers from Africa, Central America and the South Pacific. Photo: Ericka Witcher.

plants. In areas where there has been little weathering of the bedrock to make soil, tree roots, along with leaf litter, can hasten this process simply by growing in it (Lutz \& Griswold, 1939). Soil development with increased loam means lessened root pressure, more mycorrhizae, better CEC and nutrient retention, which all lead to healthier plants (Scharenbroch et al., 2013). The south end of the MBC property has seven beds which tie together many of these principles. Although higher in elevation and thus with bedrock nearer the surface and in some places exposed, there are many old oaks with spreading root systems and broad canopies, shedding acidic leaves high in tannins throughout the year into the soil. These oaks, combined with a few fast-growing Albizia saman (monkeypod) trees and grand Sabal causiarum (Puerto Rican hat palm), have created a sheltered space with well-drained, relatively nutrient-rich soil for cycads from Africa, Asia, Central America and the South Pacific, whose roots in turn reinforce the root plates of the trees themselves and contribute to the underground microbiota (Fig. 4).

Conversely, in places where the soil is not stable or is in danger of erosion, such as in tidal areas or flood zones, tree roots operate as stabilisers to establish planting areas for water-loving plants. The low-elevation areas at MBC are at or below sea level, and there are many palms and trees that have been planted there with this in mind. Nypa palms guard the banks of one lake (Fig. 5), while Heritiera littoralis (Dungun or looking-glass mangrove) firm up others so that other smaller plants can be planted around them. Tree 


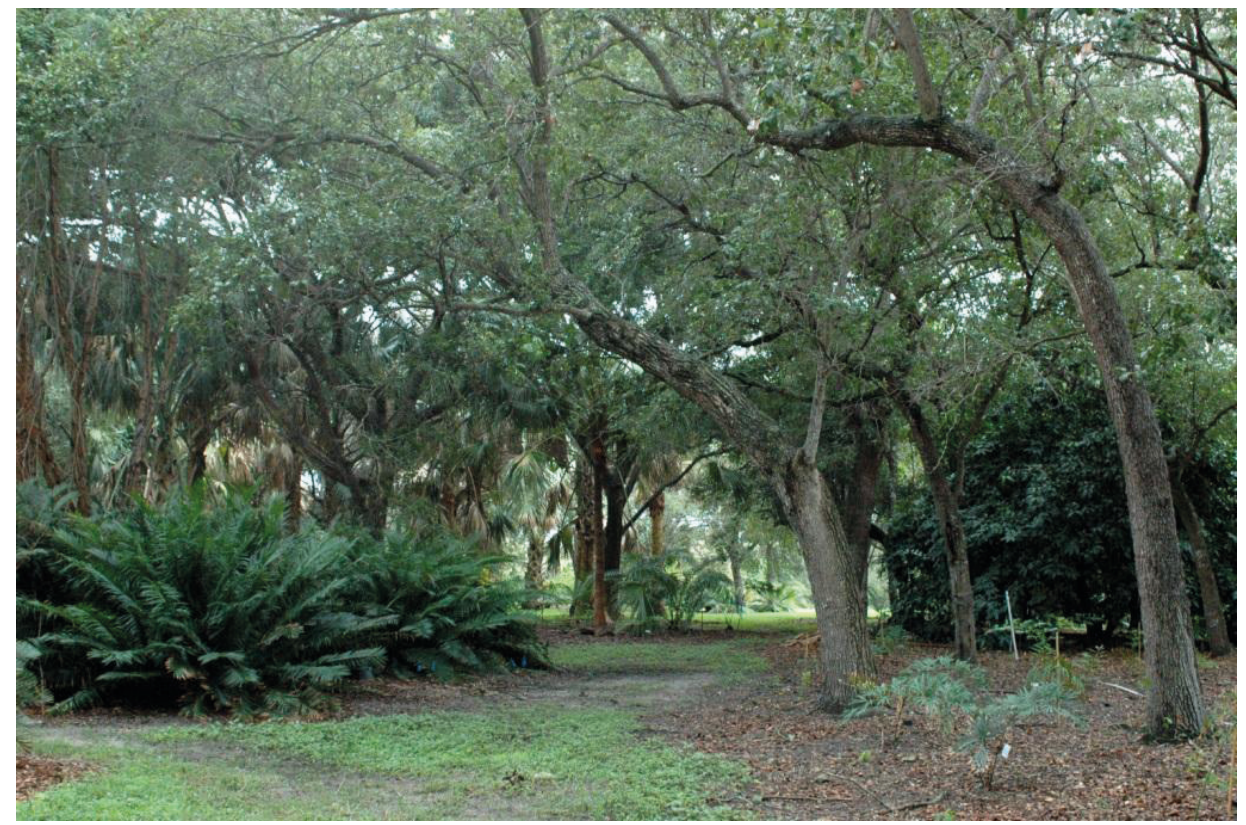

Fig. 4 Tannic leaves shed by native oaks (Quercus virginiana) break down and mix into alkaline limestone soil, creating a more agreeable habitat for a new planting of Cycas debaoensis (bottom right), now among cycads from four other continents. Photo: Ericka Witcher.

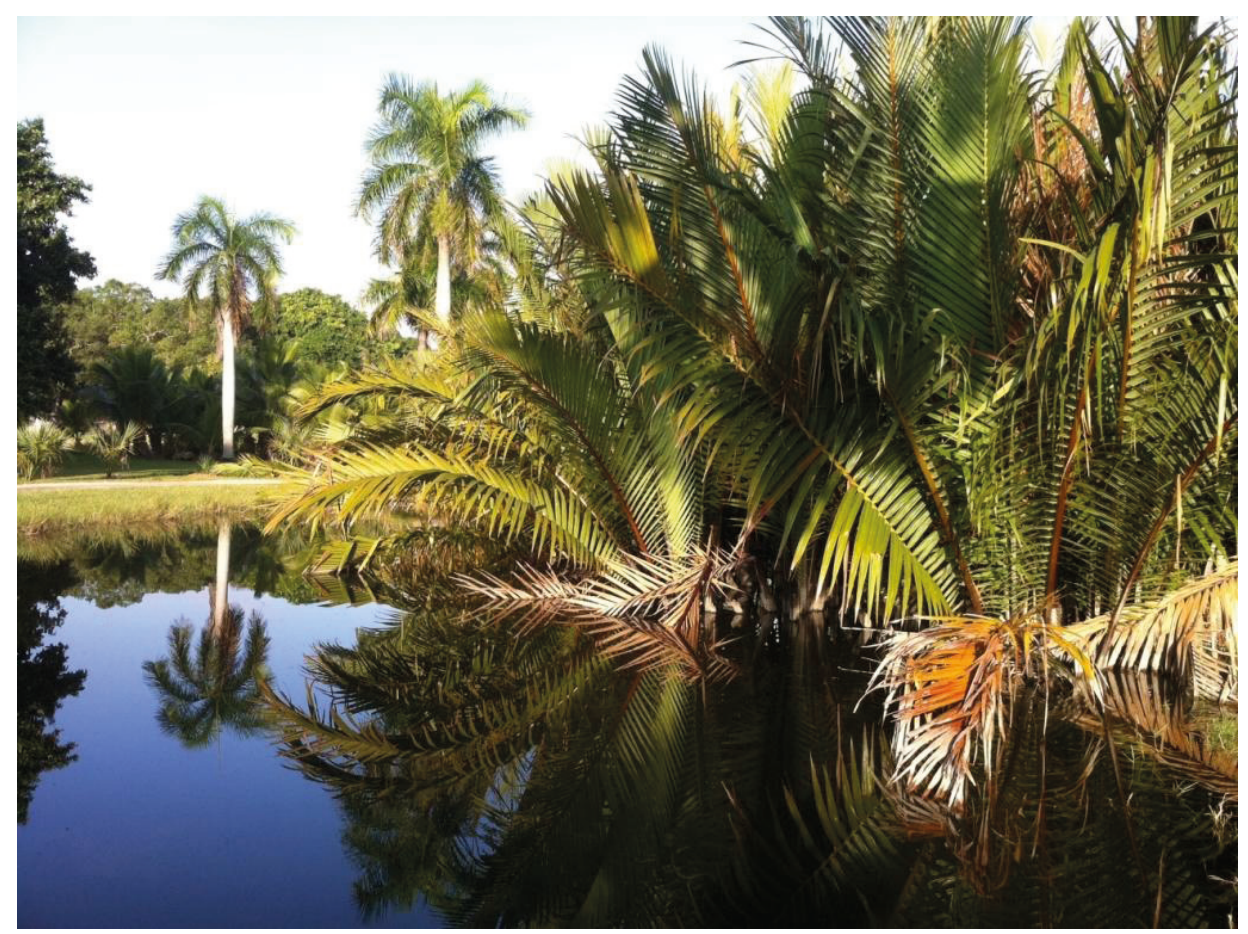

Fig. 5 Nypa fruticans reinforces the marl bank of a small lake, supporting other small plants growing nearby. Photo: Ericka Witcher. 
roots provide soil aeration in their immediate vicinity, which is essential for preventing root rot in these marl areas.

Storms also play a huge role in the life of any plant living in South Florida, unfortunately. Thunderstorms occur with great regularity as do, more infrequently, tropical depressions and hurricanes. Strong, sustained winds are signatures of these events along with heavy rain. Many studies in forestry have demonstrated how open areas see much higher wind velocities compared to adjacent tree stands, and how trees themselves function to change air flow, disperse wind force and survive storms (Coutts \& Grace, 1995). Trees and palms that come from cyclone-prone regions seem particularly adapted to these functions (Griffith et al., 2013; 2008) and subsequently serve to protect their understoreys. Staff at MBC have begun to reinforce areas of the property with these plants. For example, a north-east section is backed on two sides by densely wooded natural areas, and here staff have combined sugar palms (Arenga pinnata) from Indonesia, legacy mangoes (Mangifera indica) from South East Asia, mameys (Pouteria sapote) from Mexico, Florida natives and other specimen trees throughout to create a sheltered area for future plantings of vulnerable species (Fig. 6). A Brazilian palm (Syagrus botryophora), was nearly wiped out from the collection when most of the specimens toppled in the 2005 hurricanes; the ones that remain are protected by surrounding trees or other wind-dissipating palms. In the future more specimens will be planted into these or similar areas.

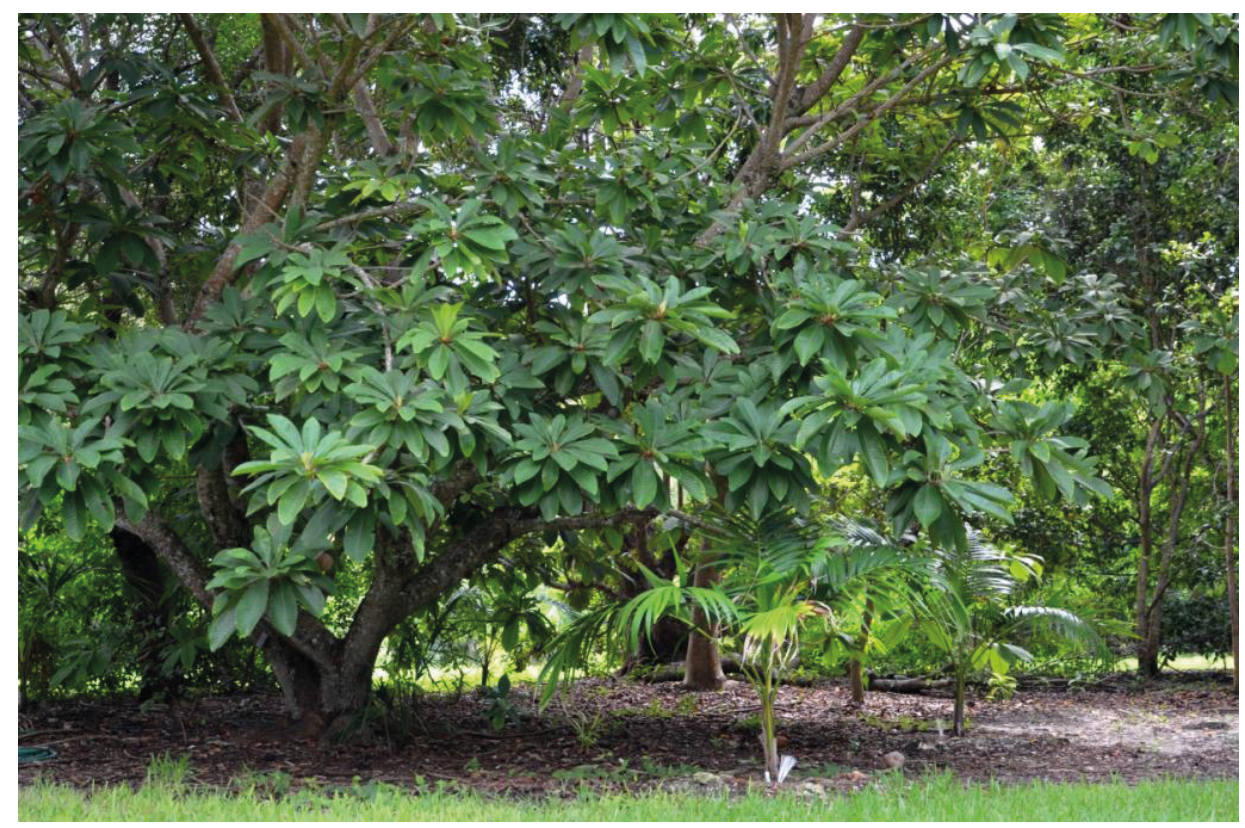

Fig. 6 A new Prestoea acuminata var. montana grows under the protective branches of an old mamey (Pouteria sapota), flanked to the east by a windbreak of native and exotic trees and shrubs. Photo: Ericka Witcher. 
As we plan for the future of the collections, the curators, field biologists and landscape architect at MBC continue to pool their collective knowledge to design and maintain habitats that will be both lovely features of the garden and suitable homes for new accessions from new places. Trees of different growth habits with varying growth rates may be added to areas. These will create shade for next year's plantings or, decades from now, provide protection from cold or wind, or otherwise change aspects of the South Florida environment to give other new plants their best chance of survival as they grow together.

The amazing plants of a botanical garden are from exotic places all over the world, but also remarkable are the new ecosystems to which they belong. If these plants are to survive in the non-native habitat of a botanic garden, then we as their caretakers must carefully consider the habitat from which they come. The role trees play in the garden ecology is the keystone of many of these constructed microhabitats. Beautiful, impressive and useful, trees are the biological topography of the botanic garden.

\section{ACKNOWLEDGEMENTS}

Thanks to Christina Dupuy, Arborist and Curator of Trees at MBC, and Chad Husby, Botanist and Collections Manager, for their ongoing work with trees on the property, and for their help; and to Joe Hibbard, ASLA, for his excellence in landscape design for MBC. Thank you too to Tracy Magellan at MBC for her help with reviewing this article.

\section{REFERENCES}

BROOKS, T.M., MITTERMEIER, R.A., MITTERMEIER, C.G., DA FONSECA, G.A.B., RYLANDS, A.B., KONSTANT, W.R., FLICK, P., PILGRIM, J., OLDFIELD, S., MAGIN, G. \& HILTON-TAYLOR, C. (2002). Habitat loss and extinction in the hotspots of biodiversity. Conservation Biology 16: 909-923.

COUTTS, M.P. \& GRACE, J. (eds) (1995). Wind and Trees. Cambridge University Press, Cambridge.

FELDHAKE, C.M. (2002). Forage frost protection potential of conifer silvopastures. Agricultural and Forest Meteorology 112(2): 123-130.

GRIFFITH, M.P., NOBLICK, L.R., DOWE, J.L., HUSBY, C.E. \& CALONJE, M. (2008). Cyclone tolerance in New World Arecaceae: biogeographic variation and abiotic natural selection. Annals of Botany 102: 591-598.

GRIFFITH, M.P, WITCHER, E., NOBLICK, L. \& HUSBY, C. (2013). Palm stem shape correlates with hurricane tolerance, in a manner consistent with natural selection. Palms 57: $115-122$.

GUERRANT, E.O., HAVENS, K. \& MAUNDER, M. (eds) (2004). Ex Situ Plant Conservation: Supporting Species Survival In The Wild. Island Press, Washington, DC.

HOBHOUSE, P. (2004). The Story of Gardening. Dorling Kindersley, London. 
LUTZ, H.J. \& GRISWOLD, F.S. (1939). The influence of tree roots on soil morphology. American Journal of Science 237: 389-400.

MAGAREY, R.D., BORCHERT, D.M. \& SCHLEGEL, J.W. (2008). Global plant hardiness zones for phytosanitary risk analysis. Scientia Agricola 65 (special edition): 54-59.

PRISM CLIMATE GROUP AT OREGON STATE UNIVERSITY \& UNITED STATES DEPARTMENT OF AGRICULTURE AGRICULTURAL RESOURCE SERVICE (2012). USDA Plant Hardiness Zone Map. Available at: http://planthardiness.ars.usda.gov (Accessed: 15 August 2013).

REICH, P.B., OLEKSYN, J., MODRZYNSKI, J., MROZINSKI, P., HOBBIE, S.E., EISSENSTAT, D.M., CHOROVER, J., CHADWICK, O.A., HALE, C.M. \& TJOELKER, M.G. (2005). Linking litter calcium, earthworms and soil properties: a common garden test with 14 tree species. Ecology Letters 8(8): 811-818.

SCHARENBROCH, B.C., MEZAA, E.N., CATANIAA, M. \& FITEB, K. (2013). Biochar and biosolids increase tree growth and improve soil quality for urban landscapes. Journal of Environmental Quality 42(5): 1372-1385.

SHASHUA-BAR, L. \& HOFFMAN, M.E. (2004). Quantitative evaluation of passive cooling of the UCL microclimate in hot regions in summer, case study: urban streets and courtyards with trees. Building and Environment 39(9): 1087-1099.

UNITED STATES DEPARTMENT OF AGRICULTURE (2013). Web Soil Survey. Available at: http://websoilsurvey.sc.egov.usda.gov (Accessed: 15 August 2013).

WITCHER, E. \& GRIFFITH, M.P. (2011). Remote sensing as a botanic garden tool. Arnoldia 69: 23-32. 
